\title{
KAJIAN KONSEP OPEN-AIR MUSEUM: STUDI KASUS KAWASAN CAGAR BUDAYA TROWULAN
}

\section{A STUDY ON THE CONCEPT OF OPEN-AIR MUSEUM: TROWULAN HERITAGE REGIONS CASE STUDY}

\author{
Wany Raharjo Wahyudi ${ }^{1}$ dan Kuswanto ${ }^{2}$ \\ ${ }^{1}$ Departemen Arkeologi, Fakultas IImu Pengetahuan Budaya, Universitas Indonesia \\ ${ }^{2}$ Balai Pelestarian Cagar Budaya Provinsi Jawa Timur \\ wanirahardjo@yahoo.co.id \\ kustpak@gmail.com
}

\begin{abstract}
This article discusses the concept of open-air museum as a kind of museum based on the new museology paradigm, within the heritage region of Trowulan. Research location is in the Heritage Region of Trowulan, Mojokerto, East Java Province. This study is a qualitative research with case studies strategy, and the research stages include data collection, data processing, and data integration (conclusion). The research results can formulate concepts and models of open-air museum that can be developed in the Cultural Heritage Regions of Trowulan. Principally, it is an open-air museum in the form of monumental buildings that located on the original site (in situ) equipped with the interpretation of human activities and integrated in an exhibition layout theme. The exhibition layout theme presented is about multicultural aspects from the Majapahit Kingdom.
\end{abstract}

Keywords: Open-air museum, Trowulan Heritage Regions, Multicultural aspect.

\begin{abstract}
ABSTRAK
Tulisan ini membahas tentang konsep open-air museum sebagai salah satu jenis museum yang berlandaskan pada paradigma new museology. Lokasi penelitian di Kawasan Cagar Budaya Trowulan, Kabupaten Mojokerto Provinsi Jawa Timur. Penelitian ini merupakan penelitian kualitatif dengan strategi studi kasus dan tahapan penelitian meliputi pengumpulan data, pengolahan data, dan integrasi data (kesimpulan). Hasil penelitian ini dapat merumuskan konsep dan model open-air museum yang dapat dikembangkan di Kawasan Cagar Budaya Trowulan. Pada intinya, open-air museum tersebut berupa bangunan-bangunan monumental yang berada di situs aslinya (in situ) disertai dengan interpretasi tentang aktivitas manusia pendukungnya yang diintegrasikan dalam sebuah tema tata pamer. Tema tata pamer yang disajikan adalah tentang aspek multikultural masa Kerajaan Majapahit.
\end{abstract}

Kata kunci : Open-air museum, Kawasan Cagar Budaya Trowulan, Aspek multikultural

Tanggal masuk : 14 Maret 2014

Tanggal diterima : 5 Mei 2014 


\section{PENDAHULUAN}

Dunia museum telah berada pada babak baru dengan paradigma new I $($ museology. Museum sebelumnya lebih berorientasi pada koleksi, sedangkan new museology lebih diarahkan pada pengembangan masyarakat (Hauenschild 1988, 9-10). New museology lebih memusatkan perhatian pada pengembangan hubungan timbal balik antara museum dan masyarakat (van Mensch 2003, 7; Magetsari 2008, 9). Perkembangan itu berpengaruh pada peran dan fungsi museum, serta berdampak pada munculnya berbagai jenis museum. Museum juga tidak hanya memelihara warisan budaya berwujud (tangible heritage), tetapi juga mulai melestarikan warisan budaya tidak berwujud (intangible heritage) atau "memori kolektif" (Hauenschild 1988, 14).

Perkembangan permuseuman, hingga saat ini telah memunculkan jenis-jenis museum yang beragam, salah satunya adalah open-air museum (Ambrose and Paine 2006, 7). Jenis museum ini muncul disebabkan oleh pesatnya pertumbuhan perkotaan pada masa revolusi industri yang menyebabkan urbanisasi, dan berdampak pada punahnya tradisi budaya setempat. Urbanisasi juga memicu meningkatnya penyeragaman budaya. Berbagai kondisi tersebut telah mendorong para intelektual yang peduli pada kebudayaan untuk mengumpulkan sisa-sisa komunitas tradisional pedesaan dan lingkungannya yang dirasa masih alami (De Jong \& Skougaard 1992, 154; Chappel 1999, 334-341). Pendirian open-air museum juga menjadi bentuk respon preventif terhadap pelestarian bangunan kuna dan lingkungannya yang terus terancam oleh laju pembangunan dan teknologi (Angotti 1982, 179-188; De Jong \& Skougaard 1992, 155).

Open-air museum merupakan museum yang terdiri dari dua bagian, yaitu bangunan yang ditampilkan secara sistematik dan bagian terbuka yang menghadirkan kehidupan masyarakat dan lingkungannya (Kostarigka 2009,
91). Koleksi museum ini berupa kawasan dan bangunan yang memiliki nilai historis dan estetis. Bangunanbangunan tua dalam kawasan situs terbuka didirikan kembali untuk dirancang dan diatur sesuai dengan keadaan pada masa lalu (Winaya 2012, 203). Oleh karena itu, jenis museum ini dapat diterapkan pada situs-situs yang tebuka, seperti di Kawasan Cagar Budaya Trowulan.

Kawasan Cagar Budaya Trowulan merupakan situs arkeologi yang terletak di Kecamatan Trowulan, Kabupaten Mojokerto, Provinsi Jawa Timur. Kawasan ini diyakini sebagai situs pemukiman bekas kota dari masa Kerajaan Majapahit, yang eksis pada abad XIII-XV (Poesponegoro 1992, 452). Berbagai macam tinggalan berupa situs pemukiman, bangunan monumental, jejak alam, dan artefak lepas banyak dijumpai pada kawasan ini. Sebagian tinggalan masih berada di tempat aslinya (insitu) dan sebagian yang berupa artefak lepas disimpan di Museum Majapahit. Oleh karena itu, situs-situs yang berada di Trowulan dapat dikatakan sebagai Kawasan Cagar Budaya karena terdiri dari beberapa situs yang letaknya berdekatan dan memiliki tata ruang yang khas (UU No 11/2010).

Kawasan Cagar Budaya Trowulan diyakini sebagai tinggalan bekas ibu kota Kerajaan Majapahit yang kompleks dan multikultural. Nilai multikultural itu sudah ada sejak masa Majapahit dan terus berlangsung hingga saat ini. Nilainilai multikultural tersebut telah menjadi inspirasi bangsa Indonesia dalam mengelola pluralisme dengan semboyan "bhineka tunggal ika" (Sedyawati dan Subroto 1993, 6).

Isu multikultural juga menjadi tema umum dalam berbagai bidang, termasuk di museum. Kebijakan Dewan Internasional Museum (ICOM) menekankan pada museum untuk menyajikan keragaman budaya. Museum telah menjadi forum untuk promosi hubungan komunitas dan perdamaian. Museum dapat menjadi tempat untuk mengatasi pemahaman budaya, ketakutan historis, dan 
ketegangan etnis. Hal itu dapat dilakukan dengan mengadopsi kebijakan keragaman budaya dihubungkan ke karya museum. Koleksi museum dapat digunakan untuk mengeksplorasi perbedaan dalam cara yang konstruktif (Crooke 2007, 81). Oleh karena itu, bentuk multikultur dari masa Majapahit dapat digali untuk mendukung penyajian open-air museum di Kawasan Cagar Budaya Trowulan.

Berdasarkan beberapa hal tersebut maka fokus kajian dalam penelitian ini adalah memperoleh pemahaman tentang konsep open-air museum, yang kemudian dapat diterapkan di Kawasan Cagar Budaya Trowulan. Oleh karena itu perlu disusun pertanyaan penelitian sebagai berikut:

1. Bagaimana rumusan konsep open-air museum yang dapat diterapkan di Kawasan Cagar Budaya Trowulan?

2. Bagaimana model open-air museum di Kawasan Cagar Budaya Trowulan?

Berdasarkan permasalahan penelitian yang telah dirumuskan, maka penelitian ini bertujuan:

1. Pengembangan konsep open-air museum di Kawasan Cagar Budaya Trowulan.

2. Memberikan alternatif pengelolaan Kawasan Cagar Budaya Trowulan sebagai open-air museum dalam rangka mendukung pelestarian dan pemanfaatan cagar budaya.

Hasil dari penelitian ini diharapkan dapat memberikan manfaat bagi berbagai pihak:

1. Bermanfaat bagi kalangan akademik sebagai bahan acuan atau referensi dalam penelitian tentang pengembangan open-air museum di Indonesia. Hasil penelitian ini juga dapat menjadi masukan bagi pengembangan ilmu Museologi untuk memperkaya kajian berkaitan dengan open-air museum. Kecuali itu, hasil penelitian ini juga dapat digunakan sebagai bahan pembelajaran bagi para siswa/mahasiswa dalam memahami eksistensi dan pelestarian Kawasan Cagar Budaya Trowulan.

2. Dapat digunakan sebagai dasar dalam pengembangan dan pengelolaan open-air museum, khususnya di Kawasan Cagar Budaya Trowulan.

3. Apabila diaplikasikan di Kawasan Cagar Budaya Trowulan diharapkan dapat mempermudah para pengunjung dalam memahami nilai penting keberadaan Kawasan tersebut. Dengan demikian, masyarakat dapat menyadari akan pentingnya pelestarian terhadap Kawasan Cagar Budaya Trowulan.

\section{KONSEP OPEN-AIR MUSEUM}

Berdasarkan rumusan International Council of Museum (ICOM) tahun 1956, open-air museum merupakan museum yang mengumpulkan, membongkar, mengangkut, merekonstruksi, dan memelihara situs sesuai aslinya. Kecuali itu, museum juga harus dilengkapi dengan elemen arsitektur asli, yang dapat memperlihatkan ciri-ciri sebagai tempat tinggal, aktifitas pertanian, atau kerajinan dari kebudayaan yang mulai punah (Laenen TT, 126). Kemudian, definisi itu dikembangkan oleh ICOM pada tahun 1957 menjadi museum yang mengoleksi objek-objek sejarah dan terbuka untuk umum. Koleksi open-air museum berupa arsitektur pra-industri yang populer, seperti rumah pedesaan, tempat perdagangan, dan arsitektur masterpieces seperti istana, gereja, atau bangunan bersejarah (Laenen TT, 127; Raswaty 2009, 47).

\section{Pada tahun 1972 The Association} of European Open-Air Museum memperluas definisi open-air museum, khususnya tentang kriteria koleksi dan pembenaran ilmiah mengenai pengetahuan tentang pemukiman, aktivitas kehidupan, bangunan, atau kompleks perdagangan yang ditata secara terintegrasi di lapangan terbuka. Berbagai objek yang disajikan juga menggambarkan tradisi yang ada di masyarakat, seperti kepercayaan, adat istiadat, dan aktivitas keseharian 
(Laenen TT, 130; Raswaty 2009, 47-48).

Secara umum, open-air museum merupakan museum yang menyajikan bangunan secara sistematik di lapangan 栾@ terbuka dan menyajikan kehidupan masyarakat beserta lingkungannya (Kostarigka 2009, 91).

Konsep open-air museum terus dikembangkan. Pada tahun 1974 ICOM memperluas cakupan museum sebagai instrumen pendidikan budaya yang dapat mengarahkan kebijakan di bidang kebudayaan, sehingga fungsi museum lebih diarahkan pada pelayanan publik. Kecuali itu, peningkatan peran pendidikan dan komunikasi museum juga diperluas dengan berorientasi pada koleksi, seperti penelitian ilmiah terhadap koleksi, penyusunan koleksi, konservasi, dan manajemen koleksi (Leanen TT, 133-134; Raswaty 2009, 48).

Berdasarkan uraian sebelumnya, dapat dirumuskan beberapa prinsip yang berkaitan dengan konsep open-air museum, yaitu prinsip bentuk, prinsip lokasi, prinsip koleksi, dan prinsip penyajian (Raswaty 2009, 53-55). Bentuk open-air museum berupa lapangan terbuka yang di dalamnya terdapat koleksi berupa bangunan bersejarah seperti bangunan pemukiman, keagamaan, perdagangan, pertanian, pertambangan, dan kuburan. Aktifitas kehidupan sosial yang sesuai dengan karakteristik bangunan juga disajikan dan dilindungi secara terintegrasi.

Lokasi open air museum berada di lapangan terbuka yang dapat terkait dengan koleksi (insitu) atau tidak terkait dengan koleksi (koleksi dipindahkan dari tempat aslinya). Dewasa ini berkembang konservasi insitu dalam open-air museum, yaitu upaya untuk merekonstruksi bangunan-bangunan kuna dengan bahan yang sama agar sesuai pada masanya (Laenen TT, 134).

Koleksi open-air museum berupa unsur-unsur arsitektur atau bangunan dan budaya populer dari masa pra industri dan revolusi industri, atau mewakili suatu aliran dari periode sejarah pada wilayah tertentu. Koleksi dapat ditempatkan di tempat asli (insitu) atau dipindahkan jika tidak dapat diselamatkan di tempat asli.

Prinsip penyajian dalam open-air museum menekankan pada kualitas visual dari desain bangunan dan lansekapnya. Bentuk bangunan dan kelengkapannya seperti alat-alat pertanian, transportasi, memasak, dan sebagainya menjadi sajian utama. Museum memberi makna koleksinya untuk dapat menghidupkan kembali pola kehidupan masa lalu melalui pameran interaktif. Penggunaan kostum adat, pembuatan kerajinan, pemakaian alatalat rumah tangga kuna dan aktivitas yang lain dapat menjadi sarana interaktif bagi pengunjung (Raswaty 2009, 5355).

Penyajian open-air museum perlu didukung dengan pemaknaan koleksi untuk mendapatkan gambaran aktivitas manusia yang sesuai dengan koleksi yang dipamerkan (Chappell 1999, 338). Menurut David Dean (1994, 6), pemaknaan atau interpretasi adalah tindakan atau proses penjelasan, klarifikasi, penerjemahan, atau presentasi tentang pemahaman seseorang terhadap subjek atau objek. Dalam proses pemaknaan akan dihasilkan makna baru yang diberikan oleh kurator (peneliti), artinya makna itu diciptakan berdasarkan kebutuhan dan konteks tertentu. Dengan demikian makna dari suatu koleksi bisa lebih dari satu, tergantung dari konteks pemaknaannya (Wahyudi dan Irmawati 2009, 106-107).

Menurut Hans Jörg Fürst (1991, 99), pada dasarnya koleksi museum berada pada proses kurasi, sehingga mengalami dekontekstualisasi karena sudah tercerabut dari konteks budayanya. Interpretasi terhadap koleksi dapat dilakukan dengan rekontekstualisasi koleksi melalui analisis komparasi. Tahap analisis komparasi dapat dilakukan dengan membandingkan berbagai atribut koleksi dengan memberikan konteks budayanya. Hasil rekontekstualisasi koleksi adalah terbentuknya konteks koleksi sesuai dengan karakteristiknya 
sehingga koleksi memiliki konteks budaya yang baru.

\section{MULTIKULTUR PADA MASA MAJAPAHIT}

Multikultur merupakan konsep untuk membangun kekuatan sebuah bangsa yang terdiri dari berbagai latar belakang etnik, agama, ras, budaya dan bahasa, dengan menghormati hak-hak sipil mereka, termasuk hak-hak kelompok minoritas. Gerakan ini mengakui dan menghormati hak-hak minoritas dan kelompok etnis atau pluralisme etnis (Kymlicka 1995, 15-24; 2001, 265-272).

Bentuk multikultural sudah ditemukan pada masa Kerajaan Majapahit. Pendirian Kerajaan Majapahit tidak lepas dari isu multikultural karena ketika Raden Wijaya, raja pertama Majapahit mendirikan kerajaan dibantu oleh suku Madura dan etnis Cina (Darmosoetopo 1993, 52-53). Multikultural pada masa Majapahit juga dapat dilihat dari susunan birokrasi kerajaan, khususnya dalam bidang keagamaan terdapat pejabat dharmadyaksa. Ada dua dharmadyaksa yaitu Dharmadyaksa Ring Kasaiwan/ Siwadyaksa mengurusi agama Siwa dan Dharmadyaksa Ring Kasogatan/ Buddhadyaksa untuk agama Buddha. Masing-masing dharmadyaksa dibantu oleh sejumlah pejabat keagamaan yang disebut Dharma Upapatti (Poesponegoro 1992, 454). Diantara para upapatti tersebut ada yang mengurusi sekte-sekte tertentu. Sementara itu agama lainnya, khususnya agama kaum resi (karesyan) dan para pertapa (tapaswi) diurusi oleh pejabat yang disebut Mantri Herhaji (Kartodirdjo 1993, 43).

Bukti lain tentang adanya multikultur di Majapahit adalah dari berita Cina. Berdasarkan Ying-yaiSheng-lan (1416 M) dinyatakan bahwa di negeri ini terdapat tiga macam penduduk (Groeneveldt 1960, 49-50) yaitu;

1. Pengikut Nabi Muhammad SAW yaitu orang-orang yang datang dari barat dan menetap di sini, pakaian dan makanan mereka bersih dan layak.

2. Orang-orang Cina yang berasal dari Kanton, Chang-Chou, dan Ch'üanChou (dua tempat terakhir berada di Fukien, tidak jauh dari Amoy), mereka adalah pelarian dan menetap di sini. Makanan dan pakaian mereka juga sangat baik, banyak dari mereka telah mengadopsi agama Muhammad dan menaati ajaranajarannya.

3. Penduduk asli yang sangat jelek dan kasar, ketika berpergian dengan kepala disisir dan kaki telanjang. Mereka percaya dan taat pada setan, mereka menjadi salah satu negara yang disebut negara setan dalam buku Buddhis. Makanan mereka sangat kotor dan buruk, seperti misalnya ular, semut, semua jenis serangga yang lain, dan cacing, yang dimasak dengan api, kemudian dimakan. Mereka memiliki anjing di rumah yang makan dan tidur bersama-sama dengan mereka, tanpa merasa jijik sama sekali.

Bukti adanya orang asing di Jawa pada masa lalu juga terekam dalam prasasti. Prasasti Warudu Kidul (922 M), mengabarkan tentang proses peradilan dalam kasus kewarganegaraan. Sang Dhanadi, seorang warga Warudu Kidul dituduh sebagai orang Khmer, tetapi dalam pengadilan tuduhan itu tidak terbukti. Oleh karena itu, Sang Dhanadi menolak kiteran, yaitu pajak yang dipungut dari orang asing. Pajak juga dipungut pada warga kilalan yang meliputi orang asing dari berbagai negara seperti Aryya, Bablara, Bebel, Campa, Cina, Karnntaka, Kling, Kair, Mambang, Madikira, Remin, dan Singhala (Dwijanto 1993, 228). Prasasti Balawi atau Prasasti Kertarajasa (1305 M) dari masa Majapahit menyebutkan adanya berbagai etnis asing di Majapahit. Prasasti yang berhuruf dan berbahasa Jawa Kuna itu menyebutkan adanya orang-orang asing di Majapahit dari Keling, Arya, Singhala, Karnnataka, Bahlara, Cina, Campa, Mandikira, Remin, Khmer, Bebel, dan Māmban (Priswanto 2012, 22). 
Berita tentang etnis-etnis asing di Majapahit juga dimuat dalam Kakawin Negarakrtagama. Pada pupuh 15: 1 disebutkan bahwa Majapahit bersahabat - 栾@ dengan Sangkayodyapura, Dharmmanagari, Marutma, Singhanagara, Campa, Kamboja, dan Yamana. Kemudian, pupuh 83: 4 menyebutkan bahwa Majapahit juga bersahabat dengan Jambudwipa (India), Kamboja, Cina, Yamana, Campa, Karnnataka, Goda, dan Siam (Santiko 2009, 9). Para pedagang, resi, dan pendeta merasa puas dan senang menetap di Majapahit (Zoetmulder 1985, 183; dalam Priswanto 2012, 23). Banyaknya orang asing yang berada di Majapahit juga mendapat perhatian dari penguasa (raja) Majapahit dengan mengangkat pejabat Juru Kling yang mengurusi orang asing (Santiko 2009, 9).

Keragaman budaya pada masa Majapahit dapat dikelola dengan baik sehingga menjadi kerajaan yang besar. Selain tampak dari struktur birokrasi pengelolaan keragaman budaya pada masa Majapahit juga diberitakan dalam kakawin dari masa Majapahit. Kakawin Sutasoma karya Mpu Tantular menggambarkan bahwa keberagaman agama pada masa Majapahit dapat dipersatukan dalam suatu rumusan kata-kata "bhinneka tunggal ika tan hana dharmma magrwa". Rumusan itu berarti berbeda-beda tetapi tetap satu tidak ada kebenaran yang mendua. Pernyataan itu pada dasarnya merupakan daya kreatif untuk mengatasi masalah keanekaan agama yang perlu dikelola dalam rangka upaya bina negara pada masa Majapahit (Sedyawati dan Subroto 1993, 6).

Bukti materi tentang multikultural pada masa Majapahit juga dapat dilihat di Kawasan Cagar Budaya Trowulan. Berbagai tinggalan arkeologis dari masa Majapahit di Trowulan dapat menunjukkan bahwa Trowulan merupakan bekas kota yang multikultural. Hal itu dapat dilihat dari tinggalan yang berupa artefak lepas maupun monumen yang masih in situ. Situs Kolam Segaran, Gapura Wringin Lawang, dan Gapura Bajang Ratu merupakan tinggalan monumental yang menunjukkan kejayaan Trowulan di masa lalu.

Sementara itu, beberapa koleksi artefak lepas di Museum Majapahit dapat menunjukkan adanya multikultural pada masa Majapahit, khususnya dalam keragaman agama dan etnis (multi etnis). Artefak yang berhubungan dengan keragaman agama berupa arcaarca dewa dari agama Hindu, Buddha, dan Rsi, serta koleksi nisan makam Tralaya sebagai representsi agama Islam di Majapahit. Koleksi yang berkaitan dengan agama Hindu berupa arca Dewa Trimurti (Siwa, Wisnu, Brahma), Lingga, Yoni, arca dewa Pantheon Hindu (Agastya, Durga, Ganesa, Nandi, Mahakala, dan Nandiswara). Koleksi yang berkaitan dengan agama Buddha berupa kepala arca Buddha, arca Dewi Tara, arca Dewi Hariti. Sementara itu koleksi yang berhubungan dengan kaum Rsi adalah arca Saptarsi.

Artefak yang menggambarkan keragaman etnis juga ditemukan di Museum Majapahit, seperti koleksi arcaarca terakota yang menggambarkan berbagai macam wajah etnis Cina, India, Arab, Persia, dan pribumi (Kusen, dkk. 1993, 240). Kecuali itu ditemukan juga mata uang logam Cina, keramik Cina, dan tulisan Arab pada nisan Tralaya. Artefak-artefak tersebut dapat menggambarkan adanya beberapa etnis (multi etnis) di masa Majapahit.

Beberapa situs yang ditemukan di Kawasan Cagar Budaya Trowulan juga dapat menunjukkan adanya keragaman agama pada masa Majapahit. Di kawasan ini ditemukan situs yang bersifat Hindu seperti Candi Tikus, Candi Menakjinggo, dan Candi Kedaton. Kemudian, terdapat situs yang bersifat Buddha, yaitu Candi Brahu dan Candi Gentong. Selain itu, juga terdapat situs yang bersifat Islam, yaitu Makam Tralaya dan Makam Putri Cempa.

Kawasan Cagar Budaya Trowulan selain memiliki situs-situs bersejarah, juga memiliki potensi kuliner, industri kerajinan, dan kesenian tradisional. Potensi kuliner berkaitan dengan perdagangan/hotel/resto dilakukan oleh 6.576 orang (BPS Kab. Mojokerto 
2012). Secara riil perkembangan sektor ini dapat dilihat dari mulai munculnya berbagai bentuk usaha rumah tangga seperti warung dan rumah makan, pertokoan, karaoke, dan penginapan. Warung-warung makan, pertokoan, dan karaoke mulai muncul di dekat area Candi Brahu Desa Bejijong. Kemudian pertokoan, warung dan rumah makan (resto), serta penginapan dapat dijumpai di kanan-kiri jalan Jombang-Surabaya mulai dari Desa Trowulan, Desa Jatipasar, dan Desa Watesumpak. Warung-warung makan, dan pertokoan juga dapat dijumpai di kanan-kiri jalan Trowulan-Sentonorejo, mulai dari Desa Trowulan dan Desa Sentonorejo, khususnya di area kompleks Makam Tralaya.

Sementara itu, sektor industri olahan juga menjadi salah satu sektor ekonomi yang menyokong Kawasan Cagar Budaya Trowulan. Sektor industri ini dilakukan oleh 6.249 orang (BPS Kab. Mojokerto 2012). Bentuk industri rumah tangga yang banyak menyokong sektor ini adalah beberapa sentra kerajinan dari bahan logam, manikmanik, batu, tanah liat, industri pembuatan bata dan pengolahan limbah plastik. Sentra kerajinan berbahan logam (cor kuningan), seperti berbagai bentuk arca, dan kerajinan manik-manik ditemukan di Desa Bejijong. Sentra kerajinan berbahan batu (pahatan batu) seperti arca, miniatur rumah, relief, dan sebagainya dapat ditemukan di Desa Jatipasar dan Watesumpak. Pembuatan kerajinan berbahan tanah liat, seperti arca, miniatur rumah, miniatur candi, dan sebagainya dapat ditemukan di Desa Trowulan. Pengolahan limbah plastik dapat ditemukan di Desa Kejagan, sedangkan industri pembuatan bata ditemukan hampir di semua desa di Kawasan Cagar Budaya Trowulan.

Selain itu, kawasan ini juga memiliki potensi di bidang kesenian lokal seperti kesenian jaranan, ujung, ludruk, bantengan, macapat, wayang kulit, dan terbang jidor. Jaranan, terbang jidor, dan macapat memang bukan kesenian asli daerah ini, tetapi sering dimainkan khususnya pada acara tertentu seperti ruwatan desa, pernikahan, dan khitanan. Khusus terbang jidor juga sering dimainkan di masjid-masjid. Kesenian bantengan, ludruk, dan ujung merupakan kesenian lokal daerah Mojokerto yang juga masih dimainkan pada acara-acara tersebut (Subaharianto 2006, 32-72).

\section{OPEN-AIR MUSEUM DI KAWASAN CAGAR BUDAYA TROWULAN}

Dalam rumusan konsep open-air museum terdapat beberapa prinsip dasar yang harus dipenuhi, seperti prinsip bentuk, prinsip lokasi, prinsip koleksi, dan prinsip penyajian. Oleh karena itu, pengembangan model openair museum di Kawasan Cagar Budaya Trowulan juga mengacu pada prinsipprinsip dasar tersebut.

Berdasarkan kajian yang telah dilakukan dapat dirumuskan bahwa konsep open-air museum di Kawasan Cagar Budaya Trowulan berupa bangunan atau struktur kuna yang masih berada di situs (in situ) dalam posisi yang tersebar di beberapa tempat. Situs-situs yang tersebar dapat diintegrasikan melalui tema tata pamer. Aktivitas manusia yang dapat ditampilkan berupa visualisasi dari hasil interpretasi di masing-masing situs.

Rumusan konsep open-air museum tersebut dapat digunakan sebagai alternatif dalam pengelolaan Kawasan Cagar Budaya Trowulan. Prinsip-prinsip konsep open-air museum dapat digunakan sebagai dasar dalam pengelolaan situs-situs di kawasan tersebut dengan acuan tiga fungsi dasar museum, yaitu melakukan konservasi, riset, dan komunikasi (van Mensch, 2003, 10). Berdasarkan kajian, pengelolaan Kawasan Cagar Budaya Trowulan menurut konsep open-air museum dapat dilakukan dengan beberapa cara:

1. Memasukkan situs-situs di kawasan tersebut sebagai koleksi open-air museum.

2. Pelestarian (konservasi) situs dapat dilakukan di situs aslinya (in situ).

3. Melakukan penelitian, terutama pemaknaan masing-masing situs untuk memperoleh gambaran 
aktivitas sosial-budaya yang akan disajikan secara terintegrasi dengan bangunannya.

4. Membuat tema tata pamer yang dapat mengitegrasikan situs-situs yang terpisah dalam sebuah rangkaian cerita.

5. Melakukan klasifikasi situs sesuai dengan tema tata pamernya.

6. Mengkomunikasikan hasil konservasi dan pemaknaan situs melalui konsep penyajian dalam open-air museum.

7. Mengintegrasikan potensi lain kawasan (kerajinan, kuliner, dan kesenian lokal) sebagai bagian dari program open-air museum sehingga menjadi kawasan yang menyatu.

Berkaitan dengan prinsip penyajian open-air museum di Kawasan Cagar Budaya Trowulan, perlu dilakukan pemaknaan koleksi untuk mendapatkan bentuk aktivitas di setiap situs sesuai dengan karakter masingmasing situs. Pemaknaan dilakukan dalam tema multikultural dari masa Majapahit untuk mendukung story line tata pamer yang akan disajikan.

Story line merupakan suatu alur atau jalan cerita yang menggambarkan keadaan suatu masa tertentu. Story line berupa skema liniar dari alur informasi pameran (Dean 1994, 103). Oleh karena itu, story line museum harus dapat menggambarkan suatu tema tertentu sebagai materi yang akan disajikan sebagai bentuk edukasi kepada masyarakat.

Berdasarkan kajian, tema yang dapat diangkat dalam penerapan openair museum di Kawasan Cagar Budaya Trowulan adalah tentang multikultur yang sudah ada pada masa Majapahit. Berkenaan dengan itu, maka story line tata pamer museum harus dapat menggambarkan bahwa Majapahit merupakan negara yang multikultur. Hal itu dapat diwujudkan dengan tata pamer open-air museum yang menggambarkan keragaman agama dan etnis pada masa Majapahit. Tiap-tiap situs dapat menyajikan aktivitas budaya yang sesuai dengan karakter situsnya, kemudian dirangkai dengan story line dalam suatu cerita tentang multikultur dari masa Majapahit.
Model open-air museum sebagai alternatif dalam pengelolaan Kawasan Cagar Budaya Trowulan dapat dibuat dalam tema multikultur. Hasil interpretasi koleksi (situs-situs) di kawasan itu semakin menguatkan adanya multikultur pada masa Majapahit. Oleh karena itu, situs-situs yang letaknya terpisah perlu diintegrasikan melalui story line dalam tema multikultur. Alur penataan pameran sesuai tema dapat disusun dalam tema multikultural, sub tema keragaman etnis, sub tema keragaman kota Trowulan pada masa Majapahit, sub tema Agama Hindu, sub tema Agama Buddha, dan sub tema Agama Islam pada masa Majapahit.

Selain itu, untuk lebih mengintegrasikan koleksi open-air museum di Kawasan Cagar Budaya Trowulan juga dapat dilakukan melalui sajian potensi kerajinan, kuliner, dan kesenian lokal sebagai program pendukung yang bersifat menghibur (intertaining) dan menyenangkan (Bruce 2006, 134). Potensi kerajinan rumah tangga yang dapat digunakan sebagai pendukung program sajian open-air museum di kawasan ini antara lain berupa kerajinan cor kuningan, kerajinan manik-manik, kerajinan pahat batu, kerajinan terakota, kerajinan kapal berbahan kayu, dan kerajinan berbahan fiber. Potensi kuliner yang dapat disajikan sebagai program pendukung adalah kuliner lokal seperti masakan rawon, soto, sambel wader, rujak cingur, dan pecel. Kemudian, kesenian lokal yang kadang masih dipentaskan seperti jaranan, bantengan, ujung, macapat, wayang kulit, ludruk, dan terbang jidor dapat dikembangkan sebagai program hiburan.

Penyajian tema multikultural dapat dimulai dengan prolog tentang gambaran multikultur pada masa Majapahit melalui tata pamer artefakartefak lepas di Museum Majapahit. Beberapa koleksi yang dapat menyimbolkan bentuk multikultural seperti arca berbagai dewa dari agama Hindu, Buddha, dan Rsi, serta koleksi nisan makam Tralaya dapat digunakan untuk menggambarkan keragaman 
agama. Kemudian, beberapa koleksi arca terakota berwajah asing seperti berwajah India, Cina, Arab/Persia, dan pribumi disertai koleksi keramik asing seperti keramik Cina, Vietnam, Thailand, dan Persia dapat digunakan untuk menggambarkan keragaman etnis di masa Majapahit.

Situs Permukiman Segaran 2, Segaran 3, dan Segaran 5 di area Museum Majapahit merupakan lokasi bekas permukiman yang di dalamnya terdapat sisa-sisa bangunan rumah dari masa Majapahit. Bangunan rumah beserta aktivitas keseharian masyarakat Majapahit dapat direkonstruksi kembali dan diintegrasikan dengan koleksi artefaktual yang dipamerkan di Museum Majapahit. Aktifitas yang dapat disajikan berupa aktivitas keseharian seperti orang memasak dengan artefak cetakan kue, gandik, dan pipisan. Orang membuat kerajinan gerabah dan logam dengan artefak tatap pelandas dan kowi. Anak-anak bermain dengan artefak kelereng dan gacuk. Orang berjual beli dengan artefak bandul timbangan, uang koin (kepeng, gobog, ma), keramik (Cina, Thailand, Vietnam). Dalam aktivitas jual beli dapat disajikan orangorang dari berbagai etnis seperti orang Cina, Arab, dan India, sehingga pameran ini dapat terintegrasi dengan tata pamer multikultural di dalam ruang pamer Museum Majapahit.

Tata pamer berikutnya bercerita tentang sub tema keragaman kota Trowulan pada masa Majapahit, yang menggambarkan kebesaran Trowulan sebagai bekas kota Majapahit. Alur pameran dimulai dari Kolam Segaran, yang menyajikan bangunan kolam besar dan luas sebagai bukti tentang kebesaran kota Trowulan pada masa lalu.

Di tengah kolam Segaran diperkirakan dahulu ada bangunan pura atau semacam bale kambang karena Segaran dianggap sebagai simbol samudera dalam konsep Astadikpalaka. Berdasarkan ajaran Hindu, letak Mahameru berada di tengah benua Jambudwipa yang dikelilingi oleh tujuh samudera dan pegunungan yang berselang-seling. Kolam Segaran dianggap sebagai simbol samudera, sehingga diduga dahulu di tengahnya terdapat bangunan sebagai simbol Mahameru, tetapi sudah rusak (Munandar 2008, 96). Selain itu, menurut cerita rakyat, dahulu di tengah Situs Kolam Segaran terdapat bangunan semacam bale kambang sebagai tempat raja-raja Majapahit menjamu tamu dari mancanegara. Dalam jamuan itu dipergunakan perkakas dari bahan emas, seperti piring, mangkuk, sendok, dan cawan. Setelah selesai perjamuan semua perakakas dari emas itu dibuang ke tengah kolam. Hal ini bertujuan untuk menunjukkan bahwa Kerajaan Majapahit merupakan negara yang kaya raya (Eriawati 2006, 14).

Aktivitas manusia yang dapat ditampilkan di situs Kolam Segaran adalah aktivitas pada pura di tengah kolam dan ativitas Raja Majapahit menerima tamu asing pada bangunan bale kambang (pura) di tengah kolam. Aktivitas itu kiranya hanya dapat diinformasikan pada papan informasi dan ilustrasi dengan media visualisasi melalui foto, karena bangunan yang diperkirakan berada di tengah kolam sekarang sudah tidak ditemukan lagi.

Sajian berikutnya adalah Gapura Wringin Lawang yang berupa bangunan gapura berbentuk candi bentar, yang berfungsi sebagai pintu masuk ke halaman profan (Atmodjo 2011 12). Aktivitas yang dapat disajikan berupa orang berjaga dan keluar masuk gapura dengan santai sehingga dapat menggambarkan suasana profan. Aktivitas itu dapat mengacu pada keterangan Nagarakrtagama pupuh 8:6 yang menyatakan bahwa para prajurit Majapahit yang berjaga pada gapura luar dapat bersendau gurau (Riana 2009, 79).

Alur pameran berikutnya berupa Gapura Bajang Ratu yang merupakan pintu gerbang paduraksa sebagai pintu masuk ke halaman/bangunan suci/sakral (Atmodjo 2011, 12). Aktivitas yang dapat disajikan berupa orang berjaga dan keluar masuk gapura tetapi dengan suasana serius, mungkin dapat dilakukan dengan masuk satu per satu, 
tidak boleh berpapasan. Sebelum masuk gapura harus ijin terlebih dahulu kepada penjaga. Hal itu dilakukan untuk menggambarkan suasana sakral, (C) seperti yang digambarkan pada Nagarakrtagama pupuh 11:1, bahwa pintu inti keraton Majapahit dijaga ketat, dari jauh orang sudah dilarang masuk (Munandar 2008, 90).

Tema tata pamer selanjutnya mulai bercerita tentang keragaman agama pada masa Majapahit. Alurnya dimulai dari sub tema Agama Hindu dengan alur pameran pertama di Candi Tikus. Pameran di situs ini menyajikan bangunan kolam petirtaan yang di tengahnya terdapat bangunan candi, sebagai tempat pemandian suci dalam agama Hindu. Fungsi Candi Tikus di masa lalu diperkirakan sebagai tempat penyucian diri dari mala (dosa) bagi yang sebagian besar bersifat Hindu (Rangkuti 2012, 18). Area situs ini juga diduga sebagai bekas tempat tinggal raja (istana) Kerajaan Majapahit (Eriawati 2007, 72-74; Munandar 2013, 26-28). Aktivitas yang mungkin dapat disajikan berupa aktivitas pemujaan dalam Agama Hindu yang dilakukan oleh bangsawan Majapahit.

Alur pameran berikutnya adalah Candi Menakjinggo. Situs ini menyajikan sisa-sisa bangunan berupa struktur bata dan batu-batu candi lepas baik yang berelief maupun polos. Menurut catatan Raffles dalam History of Java, di candi ini terdapat arca Ganesha dan arca-arca lain dari mitologi Hindu. Kecuali itu, di situs itu juga terdapat arca Garuda yang berbentuk manusia berkepala burung, orang Jawa menyebutnya sebagai arca Menakjinggo (Raffles 1817, 55; Knebell

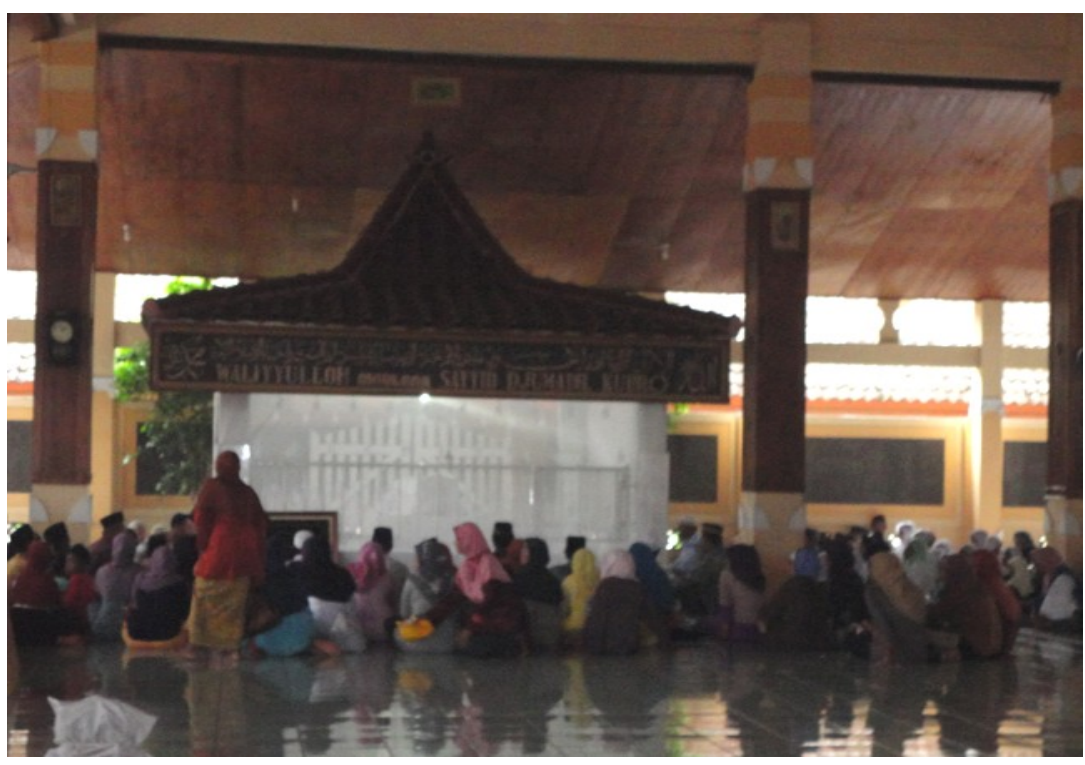

Gambar 1. Foto aktivitas ziarah kubur di Situs Makam Tralaya (Dok. Penulis)

penganut ajaran Hindu (Santiko 1985, 197-299). Oleh karena itu, aktivitas manusia yang mungkin dapat disajikan berupa acara ritual pengambilan air suci dalam Agama Hindu.

Pameran berikutnya di Candi Kedaton (Sumur Upas). Pada situs ini disajikan sisa-sisa bangunan batur candi dan struktur-struktur bata dalam area yang cukup luas. Candi Kedaton dapat dimasukkan sebagai bangunan bercorak Hindu karena di sekitar situs ini pernah ditemukan benda-benda keagamaan,
1907, 43). Aktivitas manusia yang mungkin dapat disajikan adalah pemujaan dalam Agama Hindu, tetapi karena rekonstruksi bentuk candinya belum dapat dilakukan maka aktivitas itu dapat disajikan melalui visualisasi dalam papan informasi dengan ilustrasi foto.

Berdasarkan keletakan situs maka sebaiknya tata pamer berikutnya adalah sub tema Agama Islam. Tata pameran dimulai dari Situs Makam Putri Cempa. Situs ini menyajikan bangunan cungkup yang berisi jirat dan nisan makam Putri 
Cempa, Damar Wulan, dan banyak makam lainnya. Aktivitas yang dapat disajikan berupa ziarah kubur, dan ada aktivitas ziarah yang bernuansa etnis Cina untuk menggambarkan eksistensi Putri Cempa. Dengan demikian, multikultur pada masa Majapahit dapat tergambarkan secara lebih jelas.

Tata pamer sub tema Agama Islam berikutnya adalah Situs Makam Tralaya sebagai area pemakaman orang Islam pada masa Majapahit. Di area ini disajikan cungkup-cungkup makam berisi beberapa jirat dan nisan makam tokoh-tokoh. Aktivitas yang dapat disajikan di situs ini adalah orang yang sedang berziarah kubur seperti yang masih terus berlangsung hingga saat ini
Tema tata pamer ditutup dengan sub tema Agama Buddha yaitu di Situs Candi Brahu dan Candi Gentong. Situs Candi Brahu menyajikan bangunan candi yang menjulang tinggi. Ciri Buddhis pada candi ini tampak pada adanya sisa-sisa stupa di bagian atap candi. Sementara itu, Candi Gentong menyajikan sisa-sisa struktur bata bekas bangunan candi. Berdasarkan denah tata ruangnya dapat disimpulkan bahwa konsep tata ruang Candi Gentong adalah mandala stupa, yaitu pembagian ruang yang terdiri dari pusat yang dikelilingi oleh ruangan-ruangan lain yang lebih kecil.

Berdasarkan tes carbon dating yang dilakukan pada temuan arang di

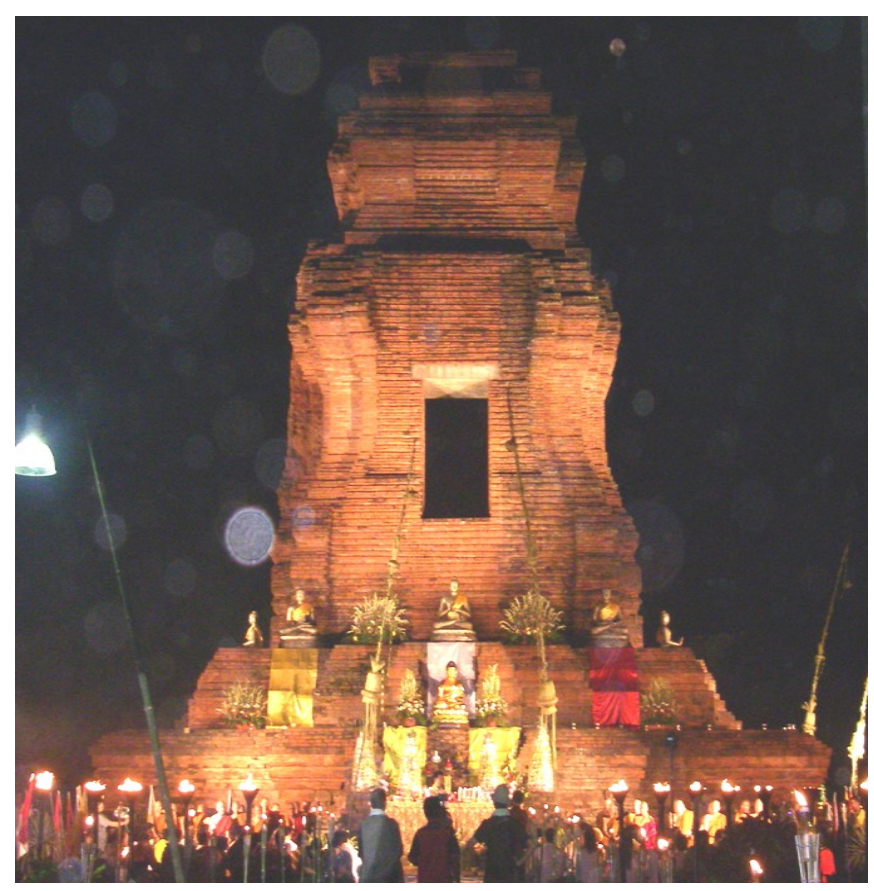

Gambar 2. Foto suasana Waisak di Candi Brahu (Dok. Penulis).

(gambar 1). Kegiatan ziarah kubur ditengarai sudah ada sebelum Islam, namun bobotnya dilebih-lebihkan sehingga di masa awal Islam Nabi Muhammad SAW melarangnya. Setelah Islam berkembang dan pemahaman umat terhadap ajaran agama sudah kuat, maka tradisi ziarah dihidupkan kembali, bahkan dianjurkan oleh nabi karena dapat mengingatkan kepada akhirat (Adrisijanti 2006, 3). situs ini diketahui analisa pertanggalan mutlak $1470 \pm 100$ AD. Dengan demikian, dapat diketahui situs ini berasal dari masa Majapahit (Kristinah dan Soviyani 2007, 137-138).

Aktivitas yang dapat disajikan pada dua area ini berupa aktivitas pemujaan dalam Agama Buddha, seperti upacara puja dan upacara Waisak dalam agama Buddha (lihat gambar 2). Pada Candi Brahu aktivitas itu dapat disajikan secara nyata, 


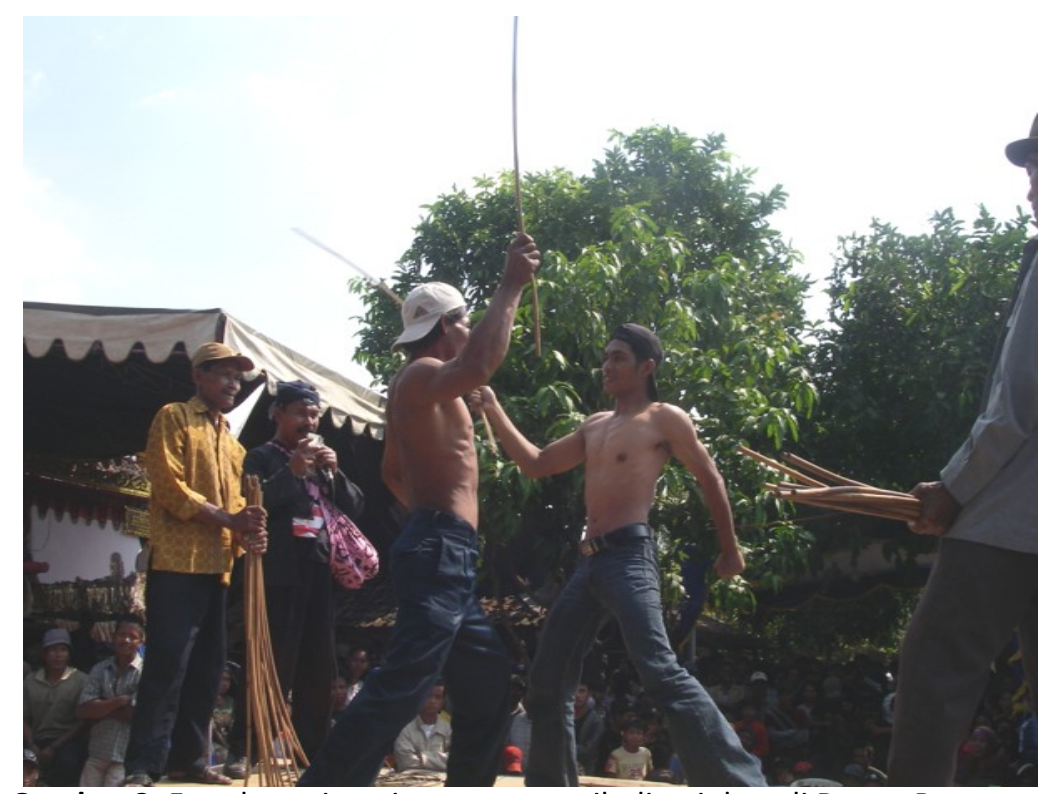

Gambar 3. Foto kesenian ujung yang masih dimainkan di Dusun Bancang, Desa Pakis, Kec. Trowulan

(Dok. Penulis)

sedangkan di Candi Gentong dapat diilustrasikan pada papan informasi melalui foto-foto yang berkaitan dengan upacara agama Buddha.

Semua aktivitas manusia pendukung setiap situs disiapkan oleh pengelola dengan figuran yang mengenakan kostum dari masa Majapahit. Kecuali itu, pengunjung juga dapat ikut berpartisipasi dalam beberapa aktivitas tersebut sehingga terdapat suasana interaktif. Desain dan model kostum yang dipakai oleh para figuran dapat mengacu dari hasil interpretasi beberapa sumber, seperti relief di beberapa batu candi dari masa Majapahit dan dokumen etnografi yang berhubungan dengan kesenian Majapahit. Model kostum itu juga dapat mengacu pada kostum para seniman yang memperagakan kesenian dari masa Majapahit, seperti yang masih berlangsung di beberapa daerah di sekitar Trowulan.

Di setiap situs perlu diberi papan pendapat bagi pengunjung. Pada papan ini pengunjung dapat memberikan pendapatnya tentang situs dan tata pamer yang disajikan sebagai bentuk partisipasi dari pengunjung. Pendapat pengunjung tersebut dapat digunakan sebagai masukan bagi pengelola dalam rangka untuk melakukan evalusai terhadap pengelolaan situs.

Sementara itu, keberadaan industri kerajinan, kuliner, dan kesenian tradisional dapat diintegrasikan sebagai program pendukung open-air museum. Pembuatan kerajinan terakota di Desa Trowulan yang menghasilkan berbagai benda seperti arca (figurin, binatang, dewa), miniatur rumah/candi dan kerajinan kapal berbahan kayu yang bernuansa Majapahit dapat diintegrasikan sebagai sajian pendukung. Berbagai bentuk kesenian tradisional seperti jaranan, bantengan, macapat, dan wayang kulit yang kadang masih dimainkan di daerah ini dapat dikembangkan untuk program pendukung dan dapat diintegrasikan dengan Kolam Segaran.

Selanjutnya kerajinan pahat batu di Desa Jatipasar dan Desa Watesumpak yang membuat berbagai macam arca, miniatur candi, yoni, dan benda lain yang bernuansa Majapahit dapat diintegrasikan dengan Gapura Wringin Lawang yang lokasinya berdekatan. Selain itu, berbagai pertokoan, rumah makan (resto), penginapan, dan tempat karaoke yang terdapat di kedua desa tersebut juga dapat dikembangkan sebagai program 
sajian pendukung. Kesenian jaranan, ludruk, dan wayang kulit yang kadang masih dipentaskan di area ini juga dapat digunakan sebagai program hiburan.

Kerajinan berbahan fiber di Desa Pakis yang menghasilkan berbagai produk hiasan, seperti bentuk buahbuahan juga dapat dikembangkan sebagai program pendukung dan diintegrasikan dengan Makam Tralaya. Kecuali itu, berbagai kios pertokoan, warung makan, dan pasar tiban yang berada di area mulai dari Desa Trowulan sampai Desa Sentonorejo dapat dikembangkan untuk menambah program pendukung yang dapat diintegrasikan dengan Museum Majapahit, Kolam Segaran, Candi Kedaton, dan Makam Tralaya. Kesenian ujung yaitu perang-perangan dengan senjata rotan yang kadang masih dimainkan di Dusun Bancang Desa Pakis dapat dikembangkan sebagai sajian pendukung yang menghibur (lihat gambar 3).

Sementara itu, berbagai warung makan dan cafe yang tersebar di kanankiri jalan antara Desa Trowulan sampai Desa Temon dapat dikembangkan untuk mendukung sajian Gapura Bajang Ratu dan Candi Tikus. Kemudian, kesenian tradisional seperti jaranan, bantengan, dan wayang kulit juga dapat menjadi program pendukung di area ini.
Sajian pembuatan kerajinan cor kuningan dan manik-manik di Desa Bejijong dapat diintegrasikan dengan Candi Brahu dan Candi Gentong yang letaknya berdekatan. Kerajinan cor kuningan ini menghasilkan berbagai macam benda bernuansa Majapahit seperti arca-arca dewa. Di Desa Bejijong juga terdapat kesenian jaranan yang dapat dikembangkan untuk sajian pendukung. Kecuali itu di area dekat Candi Brahu terdapat kios pertokoan, warung kuliner, dan tempat karaoke yang dapat diintegrasikan sebagai bentuk hiburan.

Berbagai macam bentuk kerajinan, kuliner, dan kesenian daerah seperti disebutkan sebelumnya dapat diintegrasikan dalam alur tata pamer open-air museum di Kawasan Cagar Budaya Trowulan. Alur tata pamernya tidak harus selalu dari bangunan kuna ke bangunan kuna, tetapi dapat diselingi dengan unsur hiburan (entertaining) sehingga pamernya terkesan ramai. Dengan demikian, nilai yang disajikan akan lebih populis, eksperimental, fun, dan menghibur, serta ada unsur bermain/play (Bruce, 2006: 34).

Tata pamer open-air museum di Kawasan Cagar Budaya Trowulan secara ringkas dapat disusun pada tabel berikut:

Tabel 1. Pameran tentang Kerajaan Majapahit yang dilaksanakan di Kec. Trowulan

\begin{tabular}{|c|c|c|c|}
\hline Tema & Isi pameran & Penunjang & Keterangan \\
\hline $\begin{array}{l}\text { Multikutur Pada } \\
\text { Masa Majapahit }\end{array}$ & $\begin{array}{l}\text { Prolog tentang } \\
\text { multikultur pada masa } \\
\text { Majapahit }\end{array}$ & Label informasi prolog & $\begin{array}{l}\text { Ditempatkan di bagian } \\
\text { depan ruang pamer } \\
\text { multikultur di Museum } \\
\text { Majapahit }\end{array}$ \\
\hline \multirow{4}{*}{$\begin{array}{l}\text { Sub tema; } \\
\text { Keragaman } \\
\text { agama masa } \\
\text { Majapahit }\end{array}$} & $\begin{array}{l}\text { Prolog tentang } \\
\text { Keragaman agama } \\
\text { pada masa Majapahit }\end{array}$ & Label informasi prolog & $\begin{array}{l}\text { Ditempatkan di ruang } \\
\text { pamer multikultur di } \\
\text { Museum Majapahit }\end{array}$ \\
\hline & $\begin{array}{l}\text { Koleksi Pantheon } \\
\text { Dewa Hindu }\end{array}$ & Label informasi koleksi & $\begin{array}{l}\text { Ditempatkan di ruang } \\
\text { pamer multikultur di } \\
\text { Museum Majapahit }\end{array}$ \\
\hline & $\begin{array}{l}\text { Koleksi arca Dewa } \\
\text { Trimurti (Siwa, Wisnu, } \\
\text { Brahma) }\end{array}$ & Label informasi koleksi & $\begin{array}{l}\text { Ditempatkan di ruang } \\
\text { pamer multikultur di } \\
\text { Museum Majapahit }\end{array}$ \\
\hline & $\begin{array}{l}\text { Foto candi Tikus } \\
\text { (bersifat Hindu) }\end{array}$ & informasi foto & $\begin{array}{l}\text { Ditempatkan di ruang } \\
\text { pamer multikultur di } \\
\text { Museum Majapahit }\end{array}$ \\
\hline
\end{tabular}




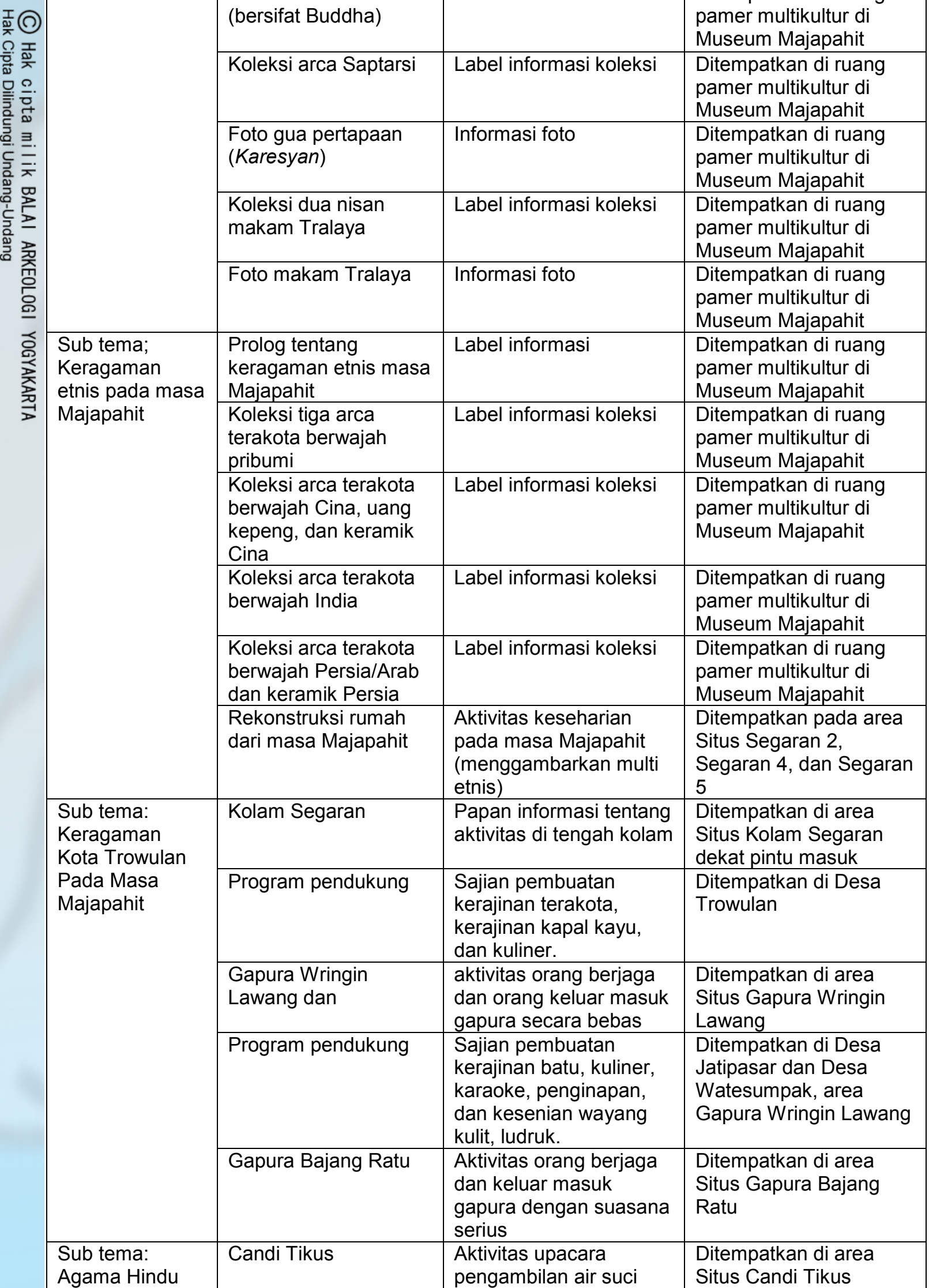


Sementara itu, potensi lain Kawasan Cagar Budaya Trowulan, seperti kerajinan, kuliner, dan kesenian tradisional dapat diintegrasikan sebagai . 作 konsep open-air museum di kawasan ini diharapkan selain dapat melestarikan situs dan bangunannya juga melestarikan cerita Bhineka Tunggal Ika dari masa Majapahit yang mulai hilang. 


\section{DAFTAR PUSTAKA}

Ambrose, Timothy dan Crispin Paine. 2006. Museum Basic (second edition). London and New York: Routledge.

Adrisijanti, Inajati Romli (ed.), dkk. 2006. Jejak Para Wali dan Ziarah Spiritual. Jakarta: Penerbit Buku Kompas.

Angotti, Thomas. 1982. Planing the Open-Air Museum and Teaching Urban History: the United States in the World Context, dalam Museum Vol. XXXIV, $n^{\circ} 3$. Hal. 179188.

Atmodjo, Yunus Satrio, dkk., 2011. Vademekum Benda Cagar Budaya. Jakarta: Kementerian Kebudayaan dan Pariwisata.

BPS Kab. Mojokerto. 2012. Kecamatan Trowulan Dalam Angka 2012.

Bruce, Chris. 2006. Spectacle and Democracy: Experience music project as a postmuseum, dalam Janet Marstine (ed.) New Museum Theory and Practice An Introduction. Victoria: Blackwell Publishing. Hal. 129-151.

Chappell, Edward A. 1999. Open-Air Museums: Architectural History for the Masses, The Journal of the Society of Architectural Historians 58(3): 334-341.

Crooke, Elizabeth. 2007. "Museum, cultural diversity, and multiculturalism". dalam Museum and Community: Ideas, Issues and Challenges. London \& New York: Routledge. Hal. 81-94.

Darmosoetopo, Riboet. 1993. Sejarah Perkembangan Majapahit, dalam Kartodirjo, Sartono, dkk. (ed). 700 Tahun Majapahit Suatu Bunga Rampai. Dinas Pariwisata Propinsi Dati I Jawa Timur. Hal. 47-63.

Dean, David. 1994. Museum Exhibition Theory and Practice. London and New York: Routledge.

De Jong, Andrian dan Skougaard, Mette. 1992. Early open-air museums: traditions of museum about traditions, dalam Museum No. 175. (Vol. XLIV, $\left.n^{\circ} 3,1992\right)$. Paris: Unesco. Hal. 151-157.

Dwiyanto, Djoko. 1993. Perpajakan Pada Masa Majapahit, dalam Kartodirjo, Sartono, dkk. (ed). 700 Tahun Majapahit Suatu Bunga Rampai. Dinas Pariwisata Propinsi Dati I Jawa Timur. Hal. 217-234.

Eriawati, Yusmaini. 2006. Rekonstruksi Tata Letak Struktur Bangunan Kota Majapahit di Situs Trowulan, Mojokerto, Provinsi Jawa Timur. Laporan Penelitian Arkeologi. Jakarta: Puslitbang Arkenas.

2007. Pola Tata Ruang Majapahit di Situs Trowulan, Mojokerto, Jawa Timur Tahap II: Penelitian Jalur-Jalur Kanal dan Struktur Bangunan di Sentonorejo III (Studi Pemukiman Skala: Mikro-Semi Mikro-Mikro). Laporan Penelitian Arkeologi. Jakarta: Puslitbang Arkenas. 
Fürst, Hans Jörg. 1991. Material Culture Research and the Curation Process, dalam Susan M. Pearce (ed.) Museum Studies in Material Culture. Washington DC: Smithsonian Institution Press. Hal. 97 - 110.

Groeneveldt, W.P. 1960. Historical Notes on Indonesia And Malaya Compiled From Chinese Sources. C.V. Bhratara.

Hauenschild, Andrea. 1988. Claim and Reality of New Museology: Case Studies in Canada, the United States and Mexico. Disertasi Doktor Hamburg University.

Kartodirdjo, Sartono. 1993. "Masyarakat dan Sistem Politik Majapahit", dalam Kartodirjo, Sartono, dkk. (ed) 700 Tahun Majapahit Suatu Bunga Rampai. Dinas Pariwisata Propinsi Dati I Jawa Timur. Hal. 33-46

Knebell, J. 1907. Beschrijving de Hindoe Oudheiden in de Afdeeling Majakerta, dalam ROC 1907. Batavia: Albrecht \& Co.

Kostarigka, Eleni. 2009. Learning History in an Open-Air Museum: Historical ReEnactment and Understandings of History at St Fagans, National History Museum of Wales, dalam The International Journal of the Inclusive Museum Vol. 2 No. 3. Hal. 89-102.

Kristinah, Endang dan Soviyani, Aris (ed.). 2007. Mutiara-Mutiara Majapahit. Jakarta: Departemen Kebudayaan dan Pariwisata.

Kusen, Edi Triharyantoro dan Timbul Haryono. 1993. "Seni Majapahit". dalam Sartono Kartodirdjo (ed.). 700 Tahun Majapahit Suatu Bunga Rampai. Dinas Pariwisata Daerah Propinsi Dati I Jawa Timur. Hal. 237-267.

Kymlicka, Will. 1995. Multicultural Citizenship a Liberal Theory of Minority Rights. New York: Oxford University Press.

. (2001). Politics in the Vernacular: Nationalism, Multiculturalism and Citizenship. New York: Oxford University Press.

Laenen. (TT). A New Look at Open-Air Museum. Belgium: Open-air museum bokrijk.

Magetsari, Noerhadi. 2008. Filsafat Museologi. Museografia Vol. II. No. 2. Hal 5 - 15.

Munandar, Agus Aris. 2008. Ibukota Majapahit Masa Jaya dan Pencapaiannya. Jakarta: Komunitas Bambu.

Poesponegoro, Marwati Djoned dan Notosusanto, Nugroho. 1992. Sejarah Nasional Indonesia II. Jakarta: Balai Pustaka.

Priswanto, Hery. 2012. Orang-orang Asing di Majapahit, dalam Adrisijanti, Inajati (ed.). Majapahit Batas Kota dan Jejak Kejayaan di Luar Kota. Yogyakarta: Balai Arkeologi Yogyakarta. Hal. 22-34.

Raffles, Thomas Stamford. 1817. The History of Java Vol. II. London : Gilbert and Rivington, ST John's Square.

Rangkuti, Nurhadi. 2012. Batas Kota Majapahit, dalam Adrisijanti, Inajati (ed.). Majapahit Batas Kota dan Jejak Kejayaan di Luar Kota. Yogyakarta: Balai Arkeologi Yogyakarta. Hal. 4-21. 
Raswaty, Retno. 2009. Konsep Museum Situs dan Open-Air Museum Indonesia Tinjaun Kasus pada Taman Onrust, Museum Kepurbakalaan Banten, dan Taman Mini Indonesia Indah. Tesis Arkeologi FIB UI.

Riana, I Ketut. 2009. Kakawin Dēśa Warṇnana uthawi Nāgarakṛtagama Masa Keemasan Majapahit. Jakarta: Penerbit Buku Kompas.

Santiko, Haryani. 1985. Durga Laksmi di Jawa Tengah. PIA III, 1985.

2009. Budaya Indonesia di Masa Lampau (abad IV - XVII). Makalah pada seminar Kebudayaan Indonesia Merupakan Kunci Perekat Bangsa. Jakarta: TMII.

Sedyawati, Edi dan Subroto. 1993. Bhineka Tunggal Ika Tan Hana Dharmma Mangrva Sebuah Konsep Yang Dirumuskan di Zaman Majapahit Abad ke-14, dalam Kartodirdjo, Sartono (ed.). 700 Tahun Majapahit Suatu Bunga Rampai. Dinas Pariwisata Daerah Propinsi Dati I Jawa Timur.

Subaharianto, Andang. 2006. Studi Pengembangan Seni Budaya Daerah di Kabupaten Mojokerto. Laporan Penelitian. Kerjasama Badan Perencanaan Pembangunan Daerah Pemerintah Kabupaten Mojokerto dengan Lembaga Penelitian Universitas Jember.

Undang-undang No. 11 Tahun 2010 Tentang Cagar Budaya dan Penjelasannya. BPCB Jatim, Depdikbud.

Van Mensch, Peter. 2003. Museology and management: enemies or friends? Current tendencies in theoretical museology and museum management in Europe. Makalah sebagai key note speech dalam konferensi Japanese Museum Management Academy, 7 Desember 2003, di Tokyo.

Wahyudi, Wanny Rahardjo dan Irmawati M. Johan. 2009. Interpretasi dan Tata Pamer Museum. Museografia. Vol. III No. 4. Hal. 105-112.

Winaya, Atina. 2012. Pengembangan Situs Pemakaman Kolonial Sebagai Open Air Museum: Uji Coba pada Museum Taman Prasasti, dalam Supratikno Rahardjo, dkk. (ed.) Arkeologi Untuk Publik. Jakarta: IAAI. Hal. 200-211. 


\section{Lampiran}
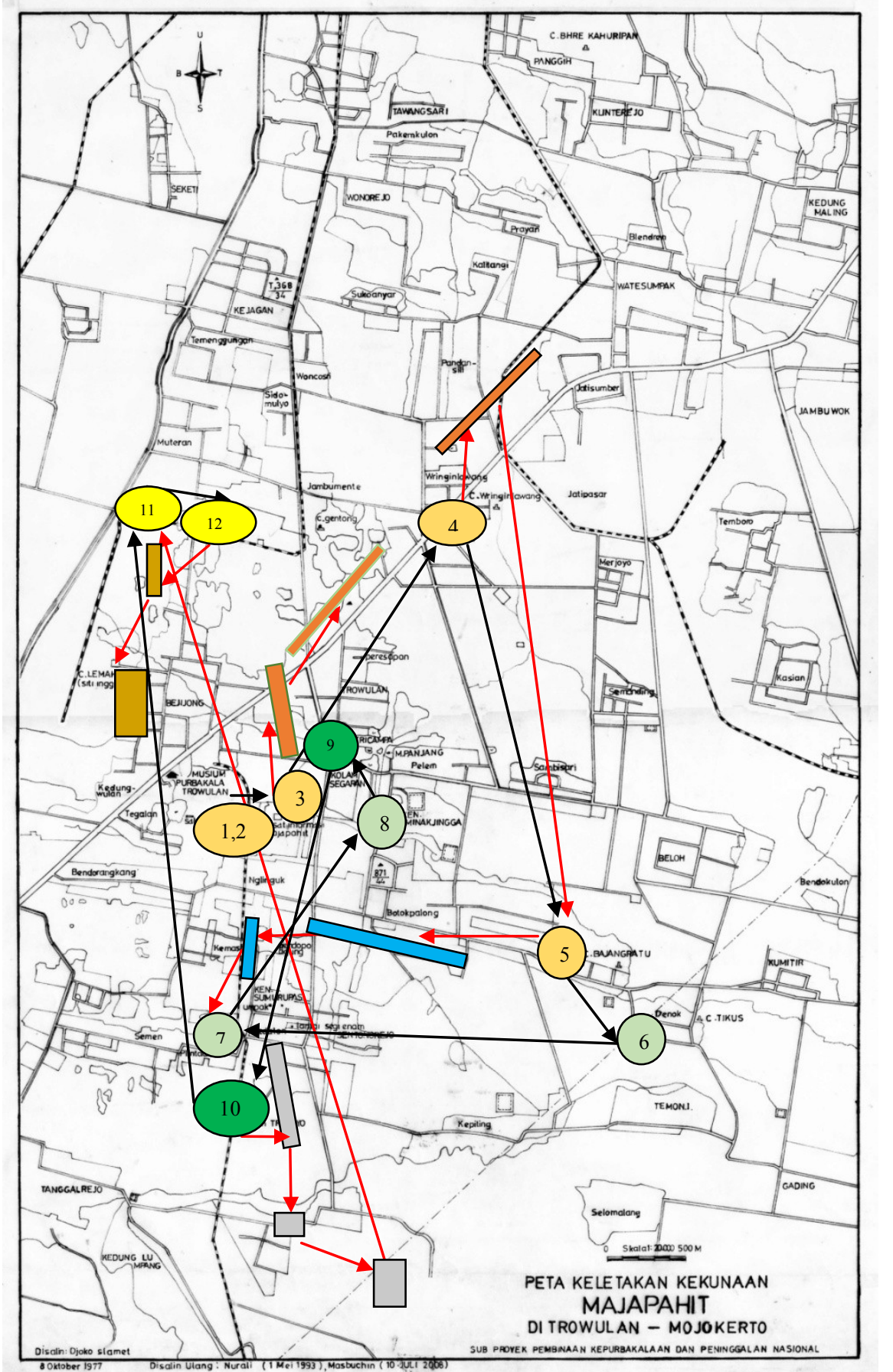

Keterangan:

1. Museum Majapahit

2. Situs Segaran 2, Segaran 4, Segaran 5

3. Kolam Segaran

7. Candi Kedaton

4. Gapura Wringin Lawang

5. Gapura Bajang Ratu

6. Candi Tikus

Tema multikultural: agama, etnis, kota

$\bigcirc$ Tema Buddha

$\rightarrow$ Alur program pendukung
8. Candi Menakjinggo

9. Candi Brahu

10. Candi Gentong

11. Makam Tralaya

12. Makam Putri Cempa

OTema Hindu

Tema Islam

$\rightarrow$ Alur tematik $\square$ kerajinan terakota, kuliner, karaoke, penginapan, ludruk, wayang kulit, jaranan

$\square$ cor kuningan, manik-manik, kuliner, jaranan

$\square$ kuliner, kafe, macapat, jaranan, bantengan

$\square$ kuliner, pasar tiban, terbang jidor, ujung, kerajinan fiber

Peta keletakan situs-situs dan alur tata pamer open-air museum di Kawasan Cagar Budaya Trowulan 